be mapped. The main coast is however too open and devoid of anchor places to rely on mapping this coast using small boats and it would seem better to use the same methods as those now in practise in Scoresby Sund.

\title{
References
}

Bondesen, E. and Henriksen, N. (1965) On some pre-Cambrian metadolerites from the central Ivigtut region SW Greenland. Bull. Grфnlands geol. Unders., No. 52 (also Meddr Grфnland, Bd. 179, Nr. 2 ). Berthelsen, A. and Bridgwater, D. (1960) On the field occurrence and petrography of some basic dykes of supposed pre-Cambrian age from the southern Sukkertoppen district western Greenland. Bull. Grønlands geol. Unders., No. 24 (also Meddr Grфnland, Bd. 123, $\mathrm{Nr} .3$ ).

Bridgwater, D. and Gormsen, K. (1968) Precambrian rocks of the Angmagssalik area, East Greenland. Rapp。Grфnlands geol. Unders., Nr. 15, 61-71.

FIELD MAPPING IN THE INNER PART OF THE

SCORESBY SUND AREA, EAST GREENLAND

\section{Niels Henriksen}

A five year systematic field mapping programme in the Scoresby Sund area of East Greenland between $70^{\circ} \mathrm{N}$ and $72^{\circ} \mathrm{N}$ was begun in the summer of 1968. The expedition was based on the 1200 tons polar vessel "Martin Karlsen" which carried 2 Bell helicopters (chartered from Heliswiss, Berne) and supported a few small boats. 31 expedition members and a boat crew of 20 persons participated in the expedition which lasted approx. 2 months. The expedition members included 12 two-man geological parties of which 7 mapped in the crystalline complex in inner Nordvestfjord 
and on Bjфrneфer, 3 in the upper Palaeozoic and Mesozoic sediments of northern Jameson Land (see T. Birkelund and K. Perch-Nielsen, this report), one party mapped Tertiary basalts (see W.S. Watt, this report) and one made glaciological investigations of glaciers in the Nordvestfjord area (see O. B. Olesen and N. Reeh, this report). Approximately $8000 \mathrm{~km}^{2}$ were mapped on a scale of 1 : 50000 around inner Nordvestfjord, west of Nordbugten.

The crystalline complex

Mapping in the area around the inner part of Nordvestfjord and on Bj申rneфer has shown that it is possible to distinguish an old gneissic basement (partly reactivated) and two younger cover sequences of supracrustal rocks, locally associated with synkinematic granites, an extensive migmatised region and some late-post kinematic granites.

The basement rocks which occur in a central core area around Hinks Land are composed of light coloured banded or veined grey gneisses with frequent amphibolite schlieren and bands. The rocks are intensely deformed and exhibit a plastic style of folding with double-folding patterns.

After the first episode of deformation and plutonism in the basement a swarm of basic dykes and sills was emplaced. These dykes now occur as folded and broken metadolerites indicating that the basement was reactivated after their emplacement.

The western of the two cover sequences distinguished is found on both sides of Daugaard-Jensens Gletscher, where it forms a belt of metasediments and metavolcanics whose grade of metamorphism increases progressively from south to north. The main rock types in the belt are: dolomites, limestones, siliceous carbonates, semipelites, quartzitic rocks, greenschists, amphibolites and basic to intermediate meta-intrusives. These supracrustal rocks were folded and metamorphosed together with the bordering granites to the west, and subsequently a tillite was unconformably deposited on the granites. The tillite, which is preserved as a small and isolated occurrence, is probably of Eocambrian age.

The eastern cover sequence occurs mainly south and west of the central basement core at Hinks Land. It is several thousand metres in thickness and can be divided into a lower grey series of homogeneous and banded paragneisses with abundant basic sills, and an upper reddish brown 
series of interbanded quartzitic and argillaceous rocks. The lithological development and the thickness of the different parts on this sequence is variable, as also is the metamorphic degree.

The boundaries between both the cover sequences and their basements are generally conformable and cover and basement are often folded together. Thrust boundaries occur in some places. Autochthonous granites sometimes form thick sheets in the boundary zone between basement and cover.

The age relationship between the two cover sequences is unknown, as no direct contact between them has been found. They have, however, both been influenced by the same thrust tectonics, which can be appreciated from the fact that a thrust sheet of the eastern cover series and its underlying basement overlies in thrust contact the western cover sequence in the vicinity of Daugaard-Jensens Gletscher.

Towards the east the eastern cover sequence becomes intensely metamorphosed and migmatised and there is thus a gradual transition into the migmatites and gneisses found in the central and outer parts of Nordvestfjord. These gneisses are garnet-rich banded biotite gneisses which often contain remnants of quartzitic beds. The banded gneisses are frequently veined and almost completely digested by granitic rocks forming migmatites. Sheets of synkinematic augen gneisses and augen granites occur frequently in the gneisses and in the migmatites. On Bjфrne $\phi$ er a detailed study of a migmatitic area has shown that it is possible to distinguish several phases of migmatisation.

Late- to post-kinematic granites are found on Charcot Land and in the outer part of Nordvestfjord.

The results of the mapping confirm generally the main geological results of previous workers (Wenk 1956; Vogt 1965). However in contrast to Vogt, who interpreted the two cover sequences as representing different levels in the same series, it is preferred to regard the two cover sequences as independent until their true relationship can be demonstrated. Furthermore, the earlier investigators interpreted the two cover sequences as of Caledonian origin but this is not yet considered as proven. 


\section{References}

Vogt, P. (1965) Zur Geologie von Südwest-Hinks Land (Ostgrönland $\left.71^{\circ} 30^{\prime} \mathrm{N}\right)$. Meddr Gr $\phi$ nland, Bd. 154, Nr. 5.

Wenk, E. (1956) Alpines und ostgrönlandisch-kaledonisches Kristallin, ein tektonisch-petrogenetischer Vergleich. Verh. naturf. Ges. Base1, Bd. 67, 75-102.

\section{FIELD MAPPING IN UPPER PALAEOZOIC AND MESOZOIC SEDIMENTS OF SCORESBY LAND AND JAMESON LAND}

T. Birkelund and K. Perch-Nielsen

Work on mapping southern Scoresby Land and Jameson Land started in 1968 as part of the five years project of mapping the whole Scoresby Sund region. Three field parties spent the six-week season mapping in the northern part of the area.

One of the main problems was to correlate the existing - but not yet published - maps of the eastern part of the area (Trümpy and Grasmück, in press; Callomon, in press) with a map of the western part of the area (prepared by M.Aellen) ${ }^{+}$. Special attention was given to the comparison of the lithology of the different formations in the western and eastern parts of the Jameson Land basin.

Upper Palaeozoic sediments are exposed at the western and eastern borders of the basin, while the central part is covered by Triassic and Jurassic sediments. These were the major subject of study this year.

+) These maps and manuscripts of descriptions were placed at our disposal by the generosity of the cited authors. 